\title{
SOLVENCY INDEX AT DIFFERENTIATED LEVELS OF CORPORATE GOVERNANCE ACCORDING THE MODELS FROM ELIZABETSKY (1976), KANITZ (1978), MATIAS (1978) AND ALTMAN (1979): THE CASE OF THE BRAZILIAN ELECTRICITY SECTOR
}

Flávia Assis Carneiro de Rezende Federal University of São Carlos, Brazil E-mail: flaviaacr.87@gmail.com

Andrei Aparecido de Albuquerque Federal University of São Carlos, Brazil E-mail: andrei@dep.ufscar.br

Gustavo Henrique Silva de Souza Federal University of Alagoas, Brazil E-mail: souza.g.h.s@hotmail.com.br

Submission: 01/05/2014 Accept: 19/05/2014

\section{ABSTRACT}

This Article aimed to identify whether there is a relationship between good practices of corporate governance and the real solvency/insolvency ratio of companies from Brazilian electricity sector, using to this end, four distinct models for the solvency calculation: Elizabetsky (1976), Kanitz (1978), Matias (1978) and Altman (1979). For this, it was performed a descriptive and experimental study of discriminant type using the linear regression analysis between the periods 2007 to 2011 . The results show that there is no a consensus among the models used, because in the Elizabetsky's model, the companies analyzed show up insolvent, while in models of Kanitz and Matias the companies analyzed show up solvents, and in the Altman's model there is a balance between solvent and insolvent. Moreover, with the regression analysis, it was found that there were no standards of performance or relations between the solvency indexes and the differentiated levels of corporate governance. That is, good practices of corporate governance - that allow the insertion of the companies best levels of corporate governance listed on the stock exchange - do not necessarily imply in better solvency, as one might assume. 
DOI: 10.14807/ijmp.v5i4.229

Keywords: Solvency Index; Corporate Governance; Brazilian Electricity Sector

\section{INTRODUCTION}

In the present, there are many discussions about the consequences of misconduct of management in large corporations, having, for example, as the most serious the bankruptcy of companies. Such consequences made that the practices of corporate governance receive more attention and importance in the recent market scenario (TALAMO, 2011; KIM; LU, 2013; MIURA, et al., 2013). Specifically, according to Talamo (2011), after the scandals of Enron, Vivendi, Cirio, Parmalat and Pan Pharmaceuticals, the debates regarding to the effectiveness of good practices of corporate governance became strong and constant worldwide.

Corporate governance emerges as an intangible tool of organizational dirigibility for companies of any sector, umpiring as a vital role in improving of the structures of operation and functioning through cohesive and dynamic management practices, enabling a significant increase in efficiency and decrease of financial risks (BHAGAT; BOLTON, 2008; SILVA Jr.; JUNQUEIRA; BERTUCCI, 2009; ROSSONI; MACHADO-DA-SILVA, 2013).

In this context, several studies conducted about the financial market have found relationships between the adherence of corporate governance practices and factors such as efficiency, productivity, volatility of shares, asset performance, capital cost, sector indexes and market value (e.g., MALACRIDA; YAMAMOTO, 2006; ALMEIDA; SCALZER; COSTA, 2008; IKENAGA; AZEVEDO; PUTVINSKIS, 2009; SILVA Jr.; JUNQUEIRA; BERTUCCI, 2009; GEOCZE, 2010; SILVA, 2010; LOPES; MARTINS, 2007, 2011; ERKENS; HUNG; MATOS, 2012; GONÇALVES et al., 2012; REYNA; VÁZQUEZ; VALDÉS, 2012; FERREIRA et al., 2013; KIM; LU, 2013; MIURA et al., 2013).

Thus, this study aims to fill a gap identified in researches on corporate governance, answering the following question: The higher the corporate governance level of a company, the better the results for the solvency indexes? This study is justified by considering that good practices of corporate governance can influence positively in the management of a company. As was raised the hypothesis that the bankruptcy cases, mentioned by Talamo (2011), have placed in greater evidence the discussion regarding the effectiveness of corporate governance, this study aims to 
DOI: 10.14807/ijmp.v5i4.229

identify whether there is a relationship between good practices of corporate governance and the real solvency/insolvency ratio of companies from the Brazilian electricity sector, using to this end, four distinct models for the solvency calculation: Elizabetsky (1976), Kanitz (1978), Matias (1978) and Altman (1979).

\section{THEORETICAL BACKGROUND}

\subsection{Corporate Governance}

Once the corporate governance has become a common term among the discussions within the financial market, various didactic and managerial definitions have situated governance as a speciality, and not more as a thematic (ANDRADE; ROSSETI, 2009). In the integrative view from Ferreira et al. (2013), corporate governance should be understood as a series of internal and external mechanisms to the organization which have the purpose of synchronizing the actions of managers and the owners' interests, in order to reduce potential agency conflicts.

The purpose of corporate governance, according to La Rocca (2007), is to ensure that, by reducing the problems generated by agency conflicts, opportunistic behaviors involving agents and principals do not occur. Moreover, corporate governance contributes to limit conflicts generated by asymmetric information, through greater transparency of data available to the market. This results in lower of capital cost for companies. That is, there is a greater fundraising - a necessary condition for higher liquidity of assets -, due to investor recognition of good practices of corporate governance performed by companies.

Still, it is worth noting that the corporate governance encompasses four basic principles which are present in their conceptual framework. These principles establish essential criteria on ethical conduct which are present in the practices of the organs responsible by the corporate governance of companies (ANDRADE; ROSSETTI, 2006; MARQUES, 2007). Thus, the principles that represent the foundation that supports all approaches to the best formats of administration are, according to the definitions from Andrade and Rossetti (2006), Malacrida and Yamamoto (2006) and Marques (2007):

- Disclosure (transparency) - Obligation to provide all the information about financial and management performance, and allow access to any data for individuals interested in some information; 
- Fairness (Equity) - Treat fairly and equitably all members, managers, employees and any interested party (society at large, customers or government);

- Accountability - Accounting for all the acts of market performance or internally issues, assuming all integrally consequences related to acts or omissions;

- Sustainability (corporate responsibility) - Ensure to the sustainability, honesty, magnanimity and maintenance of the organization, aiming the longevity of the company by promoting the safety of employees and actively participating of social and environmental programs.

From this, it is understandable that the improvement of the corporate Governance activities relates directly to the establishment of better organizational structures and to the looking for a more dynamic and cohesive functioning, enabling a significant increase of productive, operational and managerial efficiency, which result in the decrease of risks and best assessment of companies by the market and the investors (ÁLVARES; GIACOMETTI; GUSSO, 2008; FERREIRA et al., 2013).

\subsection{Differentiated Levels of Corporate Governance}

Within the Brazilian model of Corporate Governance has become necessary to generate a healthy competition that could stimulate organizational improvements and valorize the companies that eventually adopt these different levels. Thus, BM\&FBovespa (2013) [Stock Exchange of São Paulo, Brazil] created the differentiated levels of corporate governance - the New Market (highest governance standard), Level 2 (intermediate governance standard) and Level 1 (low governance standard) -, which have as main objective stipulate specific and strict standards for guide the activities within the capital market. Thus, the differentiated levels are intended to enhance the relationship between the company and investors by raising liquidity and dispersal of assets in the secondary market (GEOCZE, 2010).

This format of corporate governance preconizes that the higher the level of governance, the company will have greater visibility front the market, and consequently, will have competitive advantages over its competitors (GEOCZE, 2010; BM\&FBOVESPA, 2013). So, to join one of the 3 different levels of corporate 
governance, companies should achieve to the following membership requirements stipulated by BM\&FBovespa (2013), as can be seen abridged in Table 1:

Table 1: Principal Requirements for Accession to the Differentiated Levels of Corporate Governance

\begin{tabular}{|c|c|c|c|}
\hline Types of requirements & New Market & Level 2 & Level 1 \\
\hline $\begin{array}{l}\text { Characteristics of the } \\
\text { Outstanding Stocks }\end{array}$ & $\begin{array}{l}\text { Allows only the } \\
\text { existence of } \\
\text { common stocks }\end{array}$ & $\begin{array}{l}\text { Allows the existence of } \\
\text { common and preferred } \\
\text { stocks (with additional } \\
\text { rights) }\end{array}$ & $\begin{array}{l}\text { Allows the existence of } \\
\text { common and preferred } \\
\text { stocks (conform } \\
\text { legislation) }\end{array}$ \\
\hline Minimum of Free Float & \multicolumn{3}{|c|}{ At least $25 \%$ of free float } \\
\hline $\begin{array}{l}\text { Composition of the } \\
\text { Administration Board }\end{array}$ & \multicolumn{2}{|c|}{$\begin{array}{l}\text { Minimum of } 5 \text { members of which at least } 20 \% \\
\text { must be independent with a unified term of up } \\
\text { to } 2 \text { years }\end{array}$} & $\begin{array}{l}\text { Minimum of } 3 \text { members } \\
\text { (conform legislation) }\end{array}$ \\
\hline Financial Statements & \multicolumn{2}{|c|}{$\begin{array}{c}\text { Conform Legislation and bilingual } \\
\text { (Portuguese/English) }\end{array}$} & Conform Legislation \\
\hline Granting of Tag Along & $\begin{array}{l}100 \% \text { for common } \\
\text { stocks }\end{array}$ & $\begin{array}{l}100 \% \text { for common and } \\
\text { preferred stocks }\end{array}$ & $\begin{array}{l}80 \% \text { for common stocks } \\
\text { (conform legislation) }\end{array}$ \\
\hline $\begin{array}{l}\text { Public offering of stocks } \\
\text { acquisition by minimum } \\
\text { of the economic value }\end{array}$ & \multicolumn{2}{|c|}{$\begin{array}{l}\text { Mandatory in case of capital delisting or exit } \\
\text { from segment }\end{array}$} & Conform Legislation \\
\hline $\begin{array}{l}\text { Accession to the } \\
\text { Arbitration Chamber }\end{array}$ & \multicolumn{2}{|c|}{ Obligatory } & Optional \\
\hline
\end{tabular}

Source: Adapted from BM\&FBovespa (2013).

The difference between the levels is in the modification of the composition requirements. From New Market for Levels 2 and 1, the most relevant difference is that the New Market prohibits the issuance of preferred stocks - those that the holders may have some privilege or preference, such as priority dividend distribution -, requiring companies have only ordinary shares which give equal rights to holders, including the right to vote and no restriction or privilege. Thus, it has as a result by adoption of the New Market the security control management from all owners (stockholders), ending the problems of power concentration (GEOCZE, 2010).

Moreover, the decision of companies to become listed on the New Market brings benefits to investors due to the greater transparency of information, greater security to corporate rights, improved monitoring and inspection process, greater accuracy in the pricing of stocks and risk reduction regarding to the business. Also, it provides benefits to the company such as improved corporate image, greater demand for their stocks, lower capital cost and valorization of the stocks, becoming the companies stronger and competitive, and still boosting the economy. And in turn, the stock market has benefits because there is an increased of liquidity and emissions (BM\&FBOVESPA, 2009). 
This is occurs because one of the main sources for the analysis of economic and financial situation of a company is through the disclosure of its financial data held periodically. Internally, the high management can evaluate how the economic performance of the company is. And externally, investors find the most viable alternatives of return for their applications (GEOCZE, 2010).

Several studies have attempted to prove the existence of beneficial results from good practices of corporate governance as higher stock returns, lower funding cost, volatility etc. (e.g., MALACRIDA; YAMAMOTO, 2006; ROGERS; SECURATO; RIBEIRO, 2006; ALVES; RIBEIRO; MANTESE, 2007; LOPES; MARTINS, 2007; ALMEIDA; SCALZER; COSTA, 2008; SILVA, 2010; LOPES; MARTINS, 2011; SERAFIM; GOMES, 2011; GONÇALVES et al., 2012).

Rogers, Securato and Ribeiro (2006) found that companies with high practices of corporate governance have lower exposure to external risks and can reap more benefits of economic growth compared to companies with lower practices of corporate governance. Almeida, Scalzer and Costa (2008) found that between 2000 and 2004, all companies listed in one of Differentiated Levels had assets less risky than companies in the open market. In turn, Lopes and Martins (2007) found in a study conducted between 2003 and 2006 ( $n=96$ companies), that the accession of Differentiated Levels showed in medium and long-term a reduction in the cost of third-party capital. Also, in a study conducted between 2001 and 2007, Gonçalves et al. (2012) found that the accession of Differentiated Levels has valorized the stocks of companies and has generated greater flow of roles within the financial market. And still, Silva (2010), analyzing the years from 2007 to 2009, found that the adoption of good practices of corporate governance positively influenced the volatility of companies' returns.

\subsection{Analysis of Financial Indexes}

Indexes represent the ratio between accounts or groups of accounts of financial statements and are used to analyze certain aspects of the financial and economic situation of a company and its performance (ASSAF NETO, 2002; 2010). Indexes, according to Matarazzo (2010), can be divided into (1) indexes that show aspects of the economic situation and (2) indexes that show aspects of the financial situation of a company. 
As can be visualized in Figure 1, the indexes that show the financial situation of a company are configured as structure indexes and liquidity indexes. In turn, indexes that show the economic situation of a company are configured as profitability indexes.

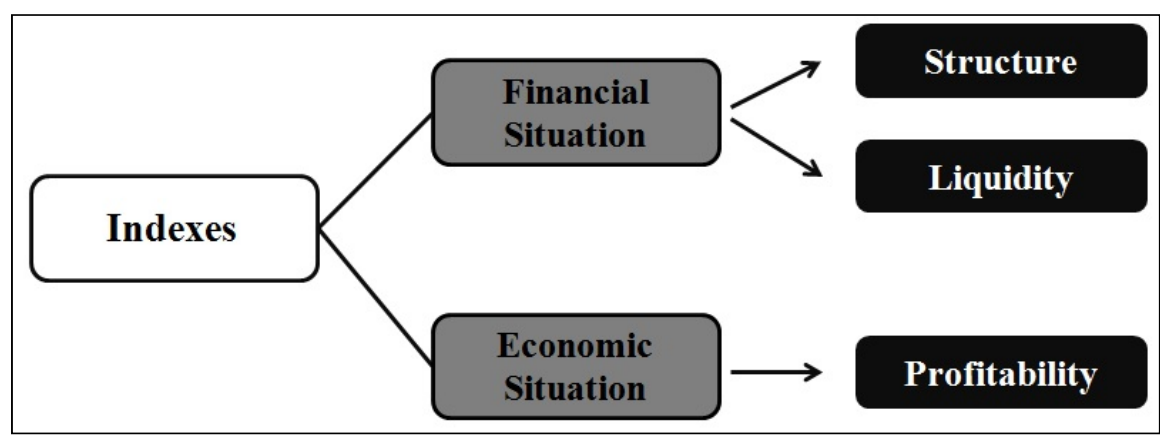

Figure 1. Economic and Financial Indexes

Source: MATARAZZO (2010, p. 84).

In its constitutive definitions, Economic and financial indexes are established as follows:

\section{Structure Indexes}

Structure indexes are linked to the capital composition of a company, i.e., the sources of capital (own or third-party). Thus, these types of indexes analyze the returns and risks on the capital structure of the company, generating information about investment, financing, dividend, profit distribution, and valorization of the company, which helps in making decision related to the application and obtaining of resources (SILVA, 2008; RIBEIRO; BOLIGON, 2009; MATARAZZO, 2010). According to Matarazzo (2010), this type of index, in general, addresses the participation of third-party capital, the composition of indebtedness, the immobilization of equity or the immobilization of non-current resources.

\section{Liquidity Indexes}

Liquidity indexes are linked to the company's ability to pay off short-term financial obligations, since they analyze the ratio between current assets and debts. Moreover, it is through these indexes that can be seen the financial situation of the company, because indicated, for example, the imminence of insolvency (RIBEIRO; BOLIGON, 2009; GITMAN, 2010; MATARAZZO, 2010). According to Matarazzo (2010), this type of index, generally, addresses the general liquidity, the current liquidity or the drought liquidity. 
DOI: 10.14807/ijmp.v5i4.229

\section{Profitability Indexes}

Profitability indexes are linked to the assessment of profits in relation to factors such as sales, assets, investments by owners or third-party capital, i.e., evaluate the company's ability to obtain profit, established as the economic result of the company (REIS, 2009; RIBEIRO; BOLIGON, 2009; GITMAN, 2010). According to Matarazzo (2010), this type of index, in general, addresses the asset turnover, net margin, the return on assets or return on equity.

\subsection{Solvency Indexes}

Inserted into the group of indexes about the financial situation of the company, the solvency prediction models have aiming to provide, in advance and reasonable safety, prediction information of default or insolvency, which may reveal possible bankruptcies (KRAUTER; SOUZA; LUPORINI, 2005; REBELLO, 2010). In general, when a company appears unable to meet its financial obligations or when your assets are less than the value of its liabilities, this company is in insolvent situation (LEV, 1978; GIMENES; URIBE-OPAZO, 2001).

Nascimento, Pereira and Hoeltgebaum (2010) find that one of the best ways to understand the companies' performance is by the insolvency measurement. Through the application of the models from Elizabetsky, Kanitz, Matias, Altman, Baidya and Dias, and Silva, the authors analyzed the financial performance of two leading Brazilian airline industry (2004 to 2008) and explained much of the marketing and economic consequences that influenced these companies financially. In turn, Baptista (2011), by the prediction models solvency of Altman, Kanitz and Matias, analyzed the performance of the largest dealerships of Brazilian highways with stocks traded on BM\&FBovespa (2000-2010). As result, the author was able to foresee financial difficulties over the period in question for the companies analyzed.

Rebello (2010) raises the major issues that a solvency index can usefully explain:

- The situation of pre-solvency;

- The hierarchizing of companies in a scale ranging of solvency to insolvency;

- Forecasts for the account "debtors doubtful" according to probability of insolvency conforms the risk level of each client. 
However, as emphasized Mario (2002) and Krauter, Luporini and Souza (2005), the calculation result of demand forecasting cannot guarantee absolutely that, if the models point insolvency, the company will actually crash and vice-versa. Moreover, Brédart (2014) reinforces the need of companies listed in corporate governance programs appeal to projects for bankruptcy protection, avoiding complete confidence in solvency indexes. Nevertheless, for the result to be as consistent as possible with the reality, according to Wang, Dennis and Tu (2007), it is important that the data of the financial statements are presented reliably and the calculations are interpreted considering market, economic, political and social issues which influencing the company investigated.

\section{METHODOLOGY}

\subsection{Type of Research}

The aim of this study is to identify whether there is a relationship between good practices of corporate governance and the real solvency/insolvency ratio of companies from the Brazilian electricity sector. Therefore, the research conducted is classified as descriptive regarding to the purpose and experimental of discriminant type with a quantitative approach regarding to analysis procedures. Descriptive research seeks to identify relationships between variables from the delimitation of criteria, assumptions and research questions. In turn, discriminant analysis, according to Assaf Neto (2002, p. 250):

It identifies the basic characteristics of a universe of variables under process of analysis, classifying it, as consequence, into categories of similar performance. Thus, through various economic-financial indicators of enterprises, the application of discriminant analysis allows one to know the typical characteristics of each business group, obtaining, thereby, the forecast factors of solvency and insolvency.

\subsection{Procedures}

Data from the companies investigated were collected in two ways. For the calculation of the solvency solvency/insolvency ratios were consulted financial statements published by the companies on their own websites. In turn, information relating to the Balance Sheet and the Statement of Income were extracted from the terminal of financial information: Bloomberg Professional (Bloomberg, 2013).

\subsection{Analysis Model}


DOI: 10.14807/ijmp.v5i4.229

Simple linear regression was used to verify the existence of positive or negative correlation between the levels of corporate governance and the results from calculations of the solvency/insolvency ratios. According to Samohyl (2009), the simple regression aims to estimate the relationship between two variables: $Y t$, commonly called variable explained, and $\boldsymbol{X t}$ commonly called variable explanatory. The equation that represents the simple regression is:

$$
Y t=a+b X_{t}+e_{t}
$$

In which, coefficients $\boldsymbol{a}$ and $\boldsymbol{b}$ must be estimated and the criteria to be used is the minimization of the error $\mathbf{e}_{\mathbf{t}}$. Once determined the values of $\boldsymbol{a}$ and $\boldsymbol{b}$ by the method of least squares, the position of the line is determined, as shown in Figure 2.

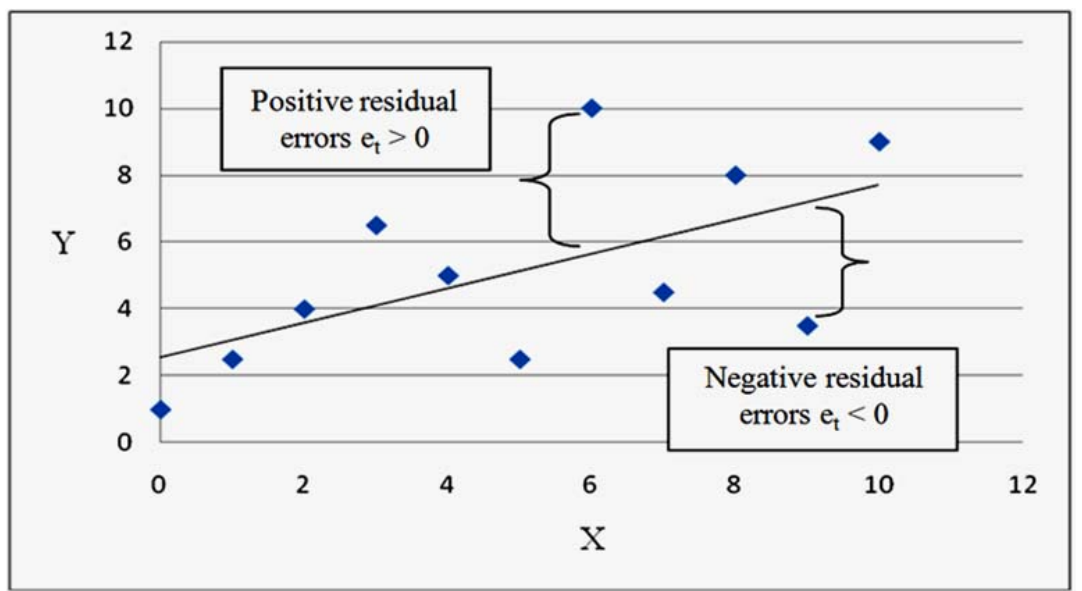

Figure 2. Straight Line Estimated of Regression in the Scatter Chart X-Y Source: Samohyl (2009, p. 201).

For the determination of the coefficients $\boldsymbol{a}$ and $\boldsymbol{b}$, the following equations are used: 3.4 Sample Selection

$$
\hat{\mathrm{a}}=\frac{\sum \mathrm{Y}_{\mathrm{t}}-\hat{\mathrm{b}} \sum \mathrm{X}_{\mathrm{t}}}{\mathrm{T}} \quad \hat{\mathrm{b}}=\frac{\mathrm{T} \sum \mathrm{X}_{\mathrm{t}} \mathrm{Y}_{\mathrm{t}}-\sum \mathrm{X}_{\mathrm{t}} \sum \mathrm{Y}_{\mathrm{t}}}{\mathrm{T} \sum \mathrm{X}_{\mathrm{t}}{ }^{2}-\left(\sum \mathrm{X}_{\mathrm{t}}\right)^{2}}
$$

For the selection of companies of the Brazilian electricity sector, 2 criteria were used: (1) companies are inserted into some of the differentiated levels of corporate governance for at least 7 years. This criterion was established, since the selection of the period for which financial information was used for the calculation of solvency indexes are from 2007 to 2011; and (2) the financial data of these companies were inserted into the Bloomberg terminal for survey and subsequent analysis. 
After using these selection criteria, we count with a sample of 11 companies of the Brazilian electricity sector [equivalent to $61 \%$ of companies of this sector listed on BM\&FBovespa $(\mathrm{N}=18)$ ], presenting as the final sample. Table 2 raises the companies selected in their respective levels of corporate governance and the date of Accession in each segment:

Table 2: Companies Selected

\begin{tabular}{l|c}
\hline New Market & Date of Accession \\
\hline CPFL Energia S.A. & $09 / 29 / 2004$ \\
\hline Light S.A. & $02 / 22 / 2006$ \\
\hline MPX Energia S.A. & $12 / 14 / 2007$ \\
\hline Tractebel Energia S.A. & $11 / 16 / 2005$ \\
\hline Level 2 & Date of Accession \\
\hline Celesc - Centrais Elétricas de Santa Catarina S.A. & $06 / 26 / 2002$ \\
\hline Eletropaulo Metropolitana Eletricidade de São Paulo S.A. & $12 / 13 / 2004$ \\
\hline Transmissora Aliança de Energia Elétrica S.A. & $10 / 27 / 2006$ \\
\hline Level 1 & Date of Accession \\
\hline Eletrobrás - Centrais Elétricas Brasileiras S.A. & $09 / 29 / 2006$ \\
\hline CESP - Cia Energetica de Sao Paulo & $07 / 28 / 2006$ \\
\hline Cemig - Cia. Energética de Minas Gerais & $10 / 17 / 2001$ \\
\hline CTEEP - Companhia de Transmissão de Energia Elétrica Paulista & $09 / 18 / 2002$ \\
\hline
\end{tabular}

Source: BM\&FBovespa (2013)

A sample of 11 companies is justified, since the companies of the survey hold together $61.13 \%$ of the Brazilian energy sector and that related studies have used sectoral samples to verify financial and accounting impacts on specific sectors, such as studies by Alves, Ribeiro and Mantese (2007) who used 10 companies from the energy sector, Macedo and Corrar (2009) who used 26 companies from the energy sector, and Serafim and Gomes (2011) who used 14 companies from the energy sector.

\subsection{Analysis: Models of Calculation of Solvency Indexes}

Since the aim of this study is to analyze solvency indexes in a discriminant perspective, we chose to use the models of calculation from Elizabetsky (1976), Kanitz (1978), Matias (1978) and Altman (1979), which are not of large complexity (compared, for example, to the technique of artificial neural networks) and all use the discriminant analysis through the treatment of quantitative data to foresee situations of solvency. That is, we calculated the insolvency indexes of the companies by applying the four models described below.

\section{Elizabetsky's Model}


DOI: 10.14807/ijmp.v5i4.229

Elizabetsky (1976) used 374 companies, in which 274 were solvents and 100 were insolvents, to build a predictive model of insolvency, by the identification of correlations between groups of indexes in a discriminant function, developing a model calculation. The model developed by Elizabetsky is represented by the following discriminant function:

$$
Y=1.93 X 1-0.21 X 2+1.02 X 3+1.33 X 4-1.13 X 5
$$

In which:

$Y=$ Insolvency Factor

$X 1=$ Net Income $/$ Sales

$X 2=$ Available $/$ Fixed Assets

$X 3=$ Receivables $/$ Total Assets

$X 4=$ Inventory $/$ Total Assets

$X 5=$ Current Liabilities $/$ Total Assets

According Elizabetsky (1976), the critical point established for their model is 0.5 , that is, values below this point indicate that the company should be classified as "insolvent" and values above this point indicate that the company should be classified as "solvent".

\section{Kanitz's Model}

Kanitz (1978), following the model of Elizabetsky, used the discriminant analysis to the construction their own insolvency prediction model, using the financial indicators whose numerical scale ranges from -7 to +7 , also known as "Kanitz's Thermometer". The Kanitz's model is represented by the following discriminant function:

$$
Y=0.05 X 1+1.65 X 2+3.55 X 3-1.06 X 4-0.33 \times 5
$$

In which:

$Y=$ Insolvency Factor

$X 1=$ Net Income $/$ Net Equity

$X 2=($ Current Assets + Long-term Assets $) /$ (Current Liabilities + Long-term Liabilities)

$X 3=$ (Current Assets - Inventories $) /$ Current Liabilities

$X 4=$ Current Assets $/$ Current Liabilities

$X 5=($ Current Liabilities + Long-term Liabilities $) /$ Net Equity 
Thus, in this model, when a company has a score between 0 and +7 , it is considered solvent. On the other hand, when a company has a score between -4 and -7 , it is considered insolvent. And companies whose results are in the range between -3 and 0 , they are considered belonging to a region of the "Kanitz's Thermometer" called "penumbra", which is not able to discriminate satisfactorily if the company can be considered solvent or insolvent.

\section{Matias' Model}

Matias (1978) used a sample of 100 companies, in which 50 of these were solvents and 50 were insolvent, to develop a solvency analysis model. The Matias' model is represented by the following discriminant function:

$$
Y=23.79 X 1-8.26 \times 2-9.87 X 3-0.76 X 4-0.54 X 5+9.91 \times 6
$$

In which:

$Y=$ Insolvency Factor

$X 1=$ Net Equity $/$ Total Assets

$X 2=$ Bank Loans $/$ Current Assets

$X 3=$ Suppliers $/$ Total Assets

$X 4=$ Current Assets $/$ Current Liabilities

$X 5$ = Operating Income $/$ Gross Profit

$X 6=$ Available $/$ Total Assets

According to Matias (1978), the critical point established for their model is 0 (zero), that is, values with negative score classified the company as insolvent, while values with positive score classified the company as solvent.

\section{Altman's Model}

In turn, Altman (1979) estimated two models, which as others mentioned, sought to identify and predict companies that have financial situations of solvency. The models developed by Altman are represented by the following discriminant function:

$$
\begin{aligned}
& Y 1=-1.44+4.03 X 2+2.25 X 3+0.14 X 4+0.42 X 5 \\
& Y 2=-1.84-0.51 X 1+6.32 X 3+0.71 X 4+0.53 X 5
\end{aligned}
$$

In which:

$$
\text { Y1 = Insolvency Factor of Model } 1
$$


DOI: 10.14807/ijmp.v5i4.229

Y2 $=$ Insolvency Factor of Model 2

$X 1=($ Current Assets - Current Liabilities $) /$ Total Assets

$X 2=$ Reserve and Earnings Retained $/$ Total Assets

$X 3=$ Total Assets

$X 4=$ Net Equity $/$ Total Assets

$X 5=$ Sales $/$ Total Assets

As the Matias' model, the critical point of the Altman's model is equal to 0 (zero) and therefore companies with results higher than zero (positive) are classified as solvents and less than zero (negative) are classified as insolvent. In this study, we considered only the equation $Y 1$ to represent the Altman's model.

\section{RESULTS}

After the calculation of the solvency indexes referring to the four models used for the five years analyzed, we came to the following results.

\section{Elizabestky's Model}

In Table 3 is possible to view the calculation of Elizabetstky's model for the companies analyzed in 3 levels of corporate governance. As pre-specified, the results below 0.5 indicate companies in insolvent situation and above this value indicate solvent situation.

Table 3: Results of Solvency Indexes for the Elizabestky's Model

\begin{tabular}{ccccc|ccc|cccc}
\hline & \multicolumn{4}{c|}{ Level 1 } & \multicolumn{4}{c|}{ Level 2 } & \multicolumn{4}{c}{ New Market } \\
\cline { 2 - 11 } & Eletrobras & Cesp & Cemig & CETEEP & Celesc & Eletropaulo & TAESA & CPFL & Light & MPX & Tractebel \\
\hline $\mathbf{2 0 0 7}$ & 0.07 & 0.06 & 0.15 & $\mathbf{0 . 7 7}$ & 0.10 & 0.07 & $\mathbf{0 . 7 5}$ & 0.15 & 0.35 & -1.31 & 0.47 \\
\hline $\mathbf{2 0 0 8}$ & 0.46 & -1.95 & 0.19 & $\mathbf{0 . 6 5}$ & 0.09 & -0.05 & 0.35 & 0.07 & 0.23 & $\mathbf{4 8 . 2 2}$ & 0.42 \\
\hline $\mathbf{2 0 0 9}$ & 0.00 & 0.28 & -0.07 & -0.03 & -0.25 & -0.97 & -1.78 & 0.11 & 0.02 & -6.60 & 0.47 \\
\hline $\mathbf{2 0 1 0}$ & -0.01 & -0.01 & 0.11 & -0.48 & -0.15 & -4.09 & -5.78 & 0.03 & -0.01 & -5.27 & 0.40 \\
\hline $\mathbf{2 0 1 1}$ & 0.04 & 0.00 & -0.06 & -4.42 & -0.21 & -3.44 & 0.31 & 0.05 & -0.07 & -4.94 & $\mathbf{0 . 5 4}$ \\
\hline \multicolumn{8}{c}{ Source: Research data. }
\end{tabular}

It is found that all the companies presented themselves insolvent in almost all years analyzed, except CETEEP (in 2007 and 2008), TAESA (in 2007), MPX (in 2008) and Tracbetel (in 2011). Indexes that constitute the solvency situation can be visualized in bold (Table 3 ).

In addition it is understood that the relationship of these indices with the levels of corporate governance not shows apparent relationships. For example, for those companies classified in the Level 1 , all proved be insolvent in all periods analyzed, except CETEEP in the years 2007 and 2008, presenting indexes of 0.77 and 0.65 
respectively. For those companies classified in the Level 2, all proved be insolvent in the years 2007 to 2011, with exception of the TAESA that in 2007 presented a result of 0.75 , indicating a solvency situation. Meanwhile, for those companies classified in the New Market, we can notice the same behavior of the indexes already displayed in the lower levels, with the exception of the Tractebel that in 2011 showed an index of 0.54 and the MPX which presented in 2008 a high index of 48.22, characterizing them in a solvency situation in those years reported. That is, solvency situation does not appear often in any level in particular.

\section{Kanitz's Model}

In Table 4 it is possible to view the calculation of the Kanitz's model for the companies analyzed in the 3 levels of corporate governance. As pre-specified, results between 0.0 and +7.0 show that the company is in a solvency situation, between -7.0 and -4.0 show that the company is in a insolvency situation, and between -3.0 and 0.0 show that the company is in the region of "penumbra" - in which cannot accurately discriminate whether the company is in a solvency or insolvency situation.

Table 4: Results of Solvency Indexes for the Kanitz's Model

\begin{tabular}{ccccc|ccc|cccc}
\hline & \multicolumn{4}{c|}{ Level 1 } & \multicolumn{3}{c|}{ Level 2 } & \multicolumn{4}{c}{ New Market } \\
\cline { 2 - 11 } & Eletrobras & Cesp & Cemig & CETEEP & Celesc & Eletropaulo & TAESA & CPFL & Light & MPX & Tractebel \\
\hline $\mathbf{2 0 0 7}$ & 8.80 & 4.81 & 5.25 & 10.53 & 5.41 & 4.51 & 7.27 & 4.16 & 5.75 & 17.38 & 4.46 \\
\hline $\mathbf{2 0 0 8}$ & 7.45 & 4.07 & 5.26 & 8.99 & 5.91 & 4.02 & 3.91 & 3.87 & 5.36 & 8.51 & 3.28 \\
\hline $\mathbf{2 0 0 9}$ & 10.25 & 4.64 & 4.13 & 10.88 & 4.84 & 4.50 & 5.91 & 4.60 & 5.87 & 6.75 & 5.52 \\
\hline $\mathbf{2 0 1 0}$ & 7.10 & 4.67 & 5.00 & 9.36 & 4.68 & 4.98 & 12.12 & 4.02 & 4.59 & 4.31 & 4.26 \\
\hline $\mathbf{2 0 1 1}$ & 6.16 & 4.87 & 3.43 & 5.60 & 5.01 & 4.94 & 4.26 & 4.61 & 4.91 & 2.58 & 5.02 \\
\hline \multicolumn{4}{c}{ Source: Research data. }
\end{tabular}

From the Kanitz's model, as can be seen in Table 4, the indexes of all companies in all years analyzed, scored higher than 0.0 indicating that all were in a solvency situation. Moreover, some indexes presented values above than +7.0 , which exceeds the standard limit of solvency, indicating external or internal occurrences to the companies (Eletrobras, CETEEP, TAESA and MPX) not explained by the data collected, but that reflect in the indexes as, for example, an increase in the purchase of stocks of these companies or a over-valorization of their assets. 
DOI: 10.14807/ijmp.v5i4.229

In Table 5 is possible to view the calculation of Matias' model for the companies analyzed in the 3 levels of corporate governance. As pre-specified, the critical point established for this model is 0.0 . Thus, results below 0.0 indicate that companies are insolvents and above this value indicate that companies are solvents.

Table 5: Results of Solvency Indexes for the Matias' Model

\begin{tabular}{ccccc|ccc|cccc}
\hline & \multicolumn{4}{c|}{ Level 1 } & \multicolumn{3}{c|}{ Level 2 } & \multicolumn{3}{c}{ New Market } \\
\cline { 2 - 10 } & Eletrobras & Cesp & Cemig & CETEEP & Celesc & Eletropaulo & TAESA & CPFL & Light & MPX & Tractebel \\
\hline $\mathbf{2 0 0 7}$ & 13.76 & 7.98 & 5.88 & 13.39 & 6.99 & 5.31 & 7.64 & 4.09 & 4.82 & 19.45 & 7.53 \\
\hline $\mathbf{2 0 0 8}$ & 8.42 & 8.99 & 6.65 & 9.95 & 7.34 & 4.27 & -3.91 & 3.53 & 4.71 & 508.2 & 1.67 \\
\hline $\mathbf{2 0 0 9}$ & 10.35 & 9.53 & 2.63 & 12.56 & 7.18 & 4.92 & 4.44 & 4.66 & 6.41 & 11.55 & 7.55 \\
\hline $\mathbf{2 0 1 0}$ & 9.90 & 6.99 & 5.07 & 11.90 & 7.25 & 5.26 & 10.33 & 2.77 & 5.03 & -4.07 & 4.11 \\
\hline $\mathbf{2 0 1 1}$ & 9.11 & 8.79 & $-\mathbf{0 . 5 9}$ & 5.49 & 7.21 & 5.80 & 0.09 & 4.11 & 4.09 & 36.55 & 7.47 \\
\hline \multicolumn{4}{c|}{ Source: Research data. }
\end{tabular}

It is found that all companies showed up solvents in almost all the years analyzed, with the exception of Cemig (in 2011), the TAESA (in 2008) and MPX (in 2010). Indexes that make up the insolvency situation can be visualized in bold. Compared to the previous model of Elizabetstky, the MPX showed in 2008 the same increase in its index (508.26), indicating an atypical situation for the company in that year.

\section{Altman's Model}

In Table 6 is possible to view the calculation of Altman's model for the companies analyzed in the 3 levels of corporate governance. As pre-specified, the Altman's model follows the same pattern of Matias' model in which the critical point is 0.0. Thus, results below 0.0 indicate that the companies are insolvent and above this value indicate that the companies are solvent. Still, we considered only the equation Y1 to represent the Altman's model.

Table 6: Results of Solvency Indexes for the Altman's Model

\begin{tabular}{|c|c|c|c|c|c|c|c|c|c|c|c|}
\hline & \multicolumn{4}{|c|}{ Level 1} & \multicolumn{3}{|c|}{ Level 2} & \multicolumn{4}{|c|}{ New Market } \\
\hline & $\begin{array}{c}\text { Eletrobr } \\
\text { as }\end{array}$ & Cesp & $\begin{array}{c}\text { Cemi } \\
\mathrm{g}\end{array}$ & CETEEP & $\begin{array}{c}\text { Cele } \\
\text { sc }\end{array}$ & $\begin{array}{c}\text { Eletropaul } \\
\text { o }\end{array}$ & $\begin{array}{c}\text { TAES } \\
\text { A }\end{array}$ & $\begin{array}{c}\mathrm{CPF} \\
\mathrm{L}\end{array}$ & Light & MPX & ractebel \\
\hline 2007 & 0.63 & -0.38 & 0.01 & 1.56 & -0.41 & -0.18 & -0.93 & -0.73 & -0.84 & -1.64 & -0.45 \\
\hline 2008 & -0.68 & -1.26 & -0.35 & 1.02 & -0.27 & -0.16 & -0.93 & -0.81 & -0.61 & -1.13 & -0.43 \\
\hline 2009 & -0.03 & -0.28 & 0.10 & 1.48 & -0.39 & 0.21 & -0.11 & -0.50 & -0.36 & -1.67 & -0.19 \\
\hline 2010 & -0.01 & -0.32 & -0.06 & 1.13 & -0.14 & 0.31 & 0.04 & -0.53 & -0.43 & -1.75 & -0.13 \\
\hline 2011 & -0.10 & -0.35 & -0.12 & 0.72 & 0.00 & 0.59 & -0.50 & -0.67 & -0.68 & -1.91 & 0.12 \\
\hline
\end{tabular}

From Altman's model, as can be seen in Table 6, the indexes of all the companies showed up more balanced and more heterogeneous than results of previous models. Indexes that constitute the solvency situation can be visualized in 
DOI: 10.14807/ijmp.v5i4.229

bold. In this model, the New Market showed greater insolvency than the Levels 1 and 2 , since that only the Tracbetel was solvent with an index of 0.12 in 2011 , while all other companies in the New Market showed up insolvent in all years analyzed.

Furthermore, with the Altman's Model, the CETEEP (Level 1) proved to be solvent in all years, following the previous models, especially of Kanitz and Matias, in which the CETEEP also was solvent in all years analyzed. In turn, at Level 2, the best results were of the Eletropaulo which showed up solvent in the years 2009, 2010 and 2011, conform the pattern found in models of Kanitz and Matias.

\section{Linear Regression Equations for Solvency Indexes}

With the data relating to solvency indexes, it was proceeded the simple linear regression to analyze the relationship between the level of corporate governance and the indexes of companies. The regression equations allow better spatial visualization of how the indexes of companies behave, verifying the correspondence between the results of the solvency indexes for all models analyzed in the five years calculated and the level of corporate governance that belong to each company, as can be seen in the graphs shown below.

As can be seen in Graphs 1, 2, 3 and 4, the vertical axis defines the results of the solvency indexes and the horizontal axis properly defines the companies grouped by levels of corporate governance to which each belongs. Thus, the first group of points in the direction from left to right on the horizontal axis of the graphs represents the companies belonging to Level 1 , the second group refers to the companies belonging to Level 2 and the third group, farthest from the axis $Y$, represents companies classified in the New Market.

Analyzing Graph 1, relative to the Elizabetsky's model, solvency indexes showed a positive correlation only in 2008. In other years, the better levels of corporate governance showed, in general, a fall in result of the solvency indexes calculated. 


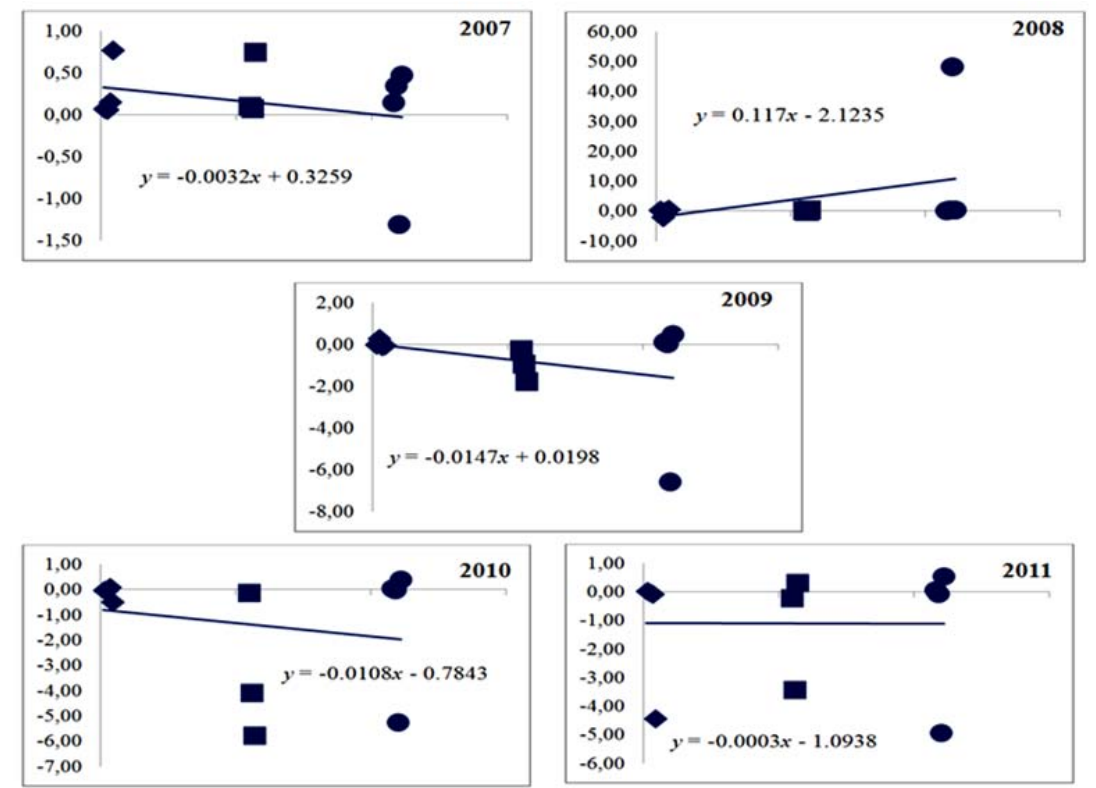

Graph 1. Elizabetsky's model for the years 2007-2011

Analyzing Graph 2, related to the Kanitz's model, solvency indexes showed a behavior with positive correlation only in 2007. During the years 2008 to 2011, however, it was found that, in general, the better level of governance corporate resulted in lower values of solvency indexes.

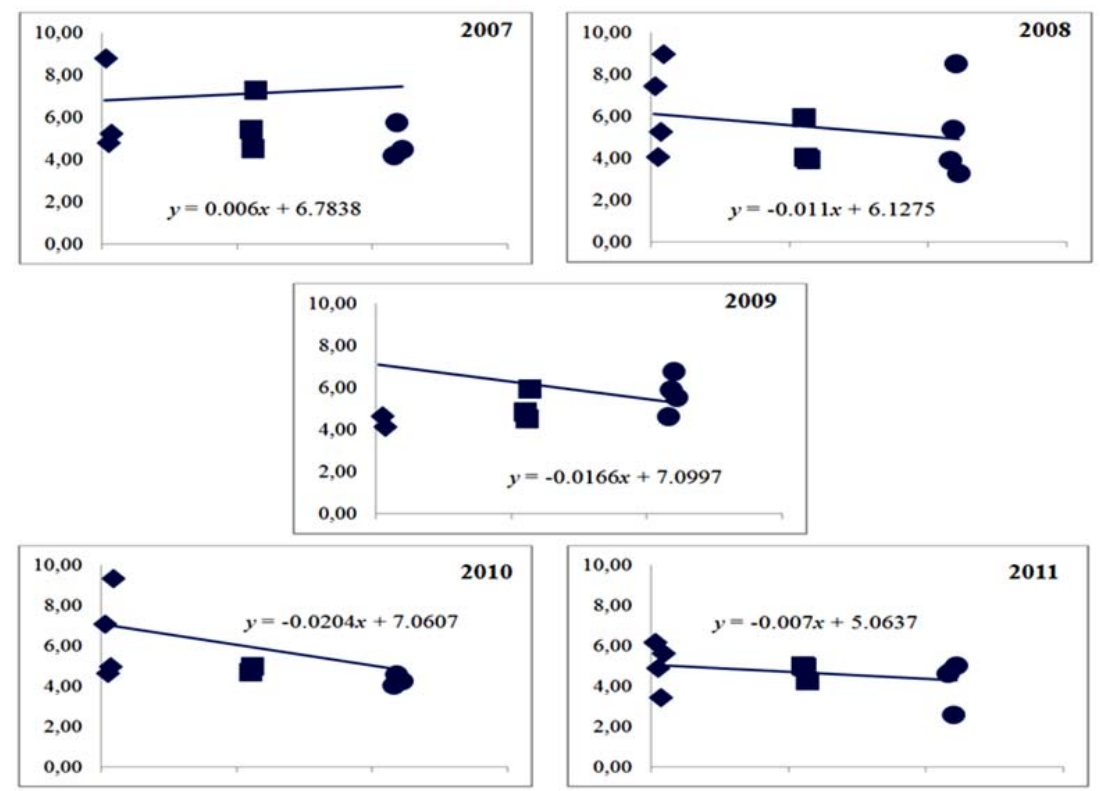

Graph 2. Kanitz's model for the years 2007-2011

Analyzing Graph 3, related to the Matias' model, solvency indexes presented a behavior with positive correlation between the level of corporate governance and solvency index only in the years 2008 and 2011. In other years, however, we have not found any correlation significant. 


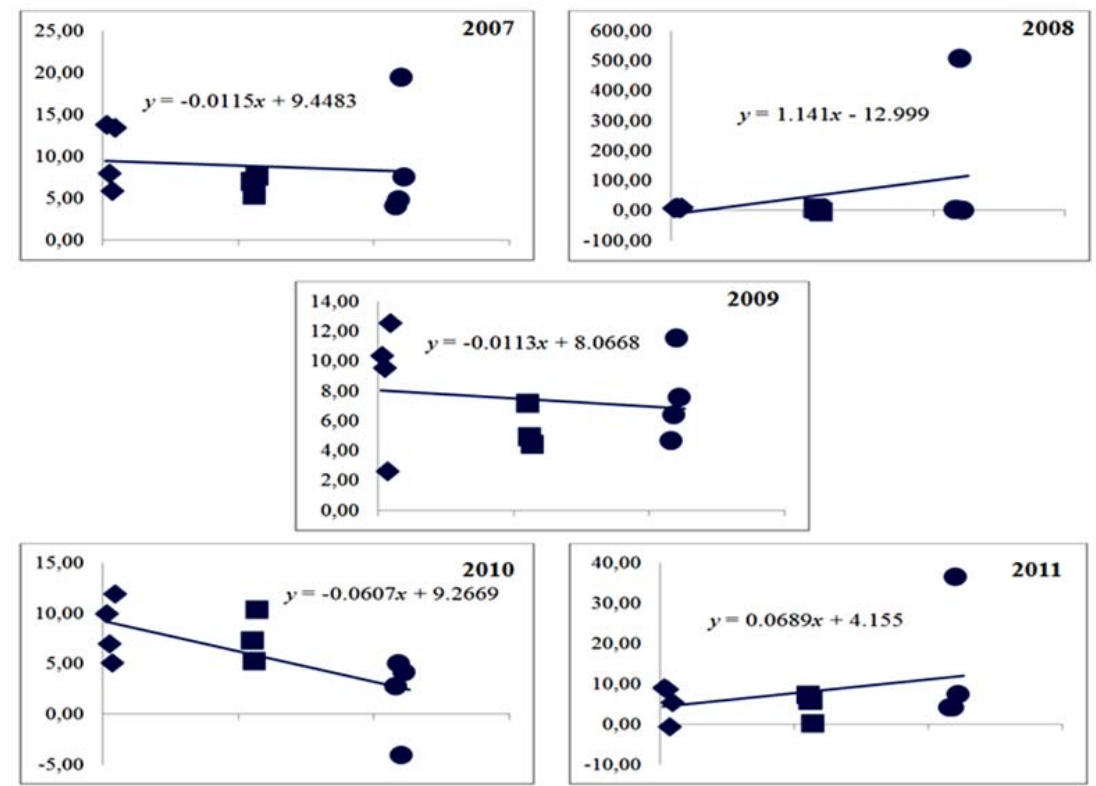

Graph 3. Matias' model for the years 2007-2011

Analyzing the Graph 4, related to the Altman's model, solvency indexes have been decreasing in all the years analyzed respecting to the level of corporate governance. Therefore, it was found for the Altman's model, a negative correlation with the level of corporate governance and solvency index.

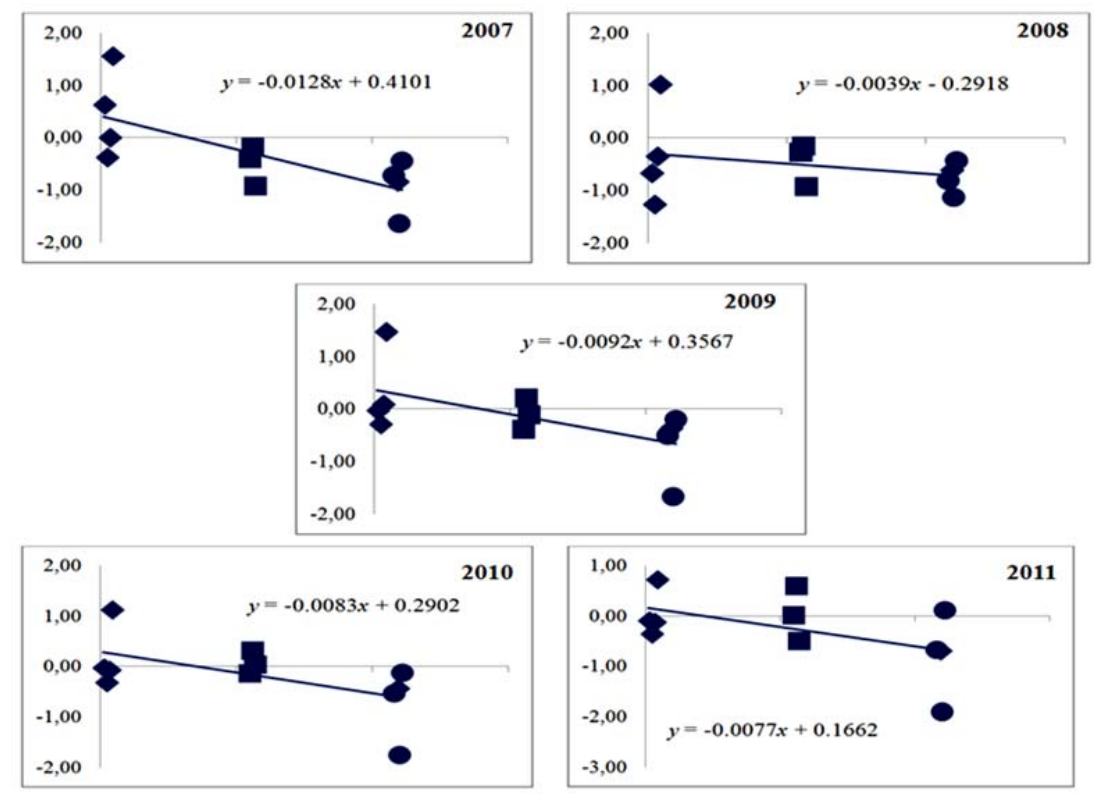

Graph 4. Altman's model for the years 2007-2011

Moreover, as can be seen in Graphs 1, 2, 3 and 4, in the analysis of the calculated indexes, the lines that describe the trend of the points were added, calculated from the simple linear regression along with the functions that represent them. Thus, if the straight line presents an increasing function implies that the 
DOI: 10.14807/ijmp.v5i4.229

solvency indexes of companies belonging respectively to Levels 1, 2 and New Market have a tendency to increasing results.

That is, for the case of an increasing straight line, i.e., with the positive linear coefficient (number that multiplies the $x$ unknown of the function $y=a x+b$ ), we have a direct correlation between the levels of corporate governance and the solvency indexes. In turn, for the case of a decreasing straight line, i.e., the negative linear coefficient, we have an indirect correlation between the levels of corporate governance and the solvency index.

Therefore, in order to identify whether the solvency indexes showed up in increasing or decreasing, the functions of simple linear regression were specified. Thus, the solvency indexes were plotted for each of the years analyzed and for all models used, as can be seen in Table 7.

Table 7: Summary of the Functions from the Solvency Indexes for the Models Used

\begin{tabular}{c|c|c|c}
\hline Model & Year & Function & Description \\
\hline \multirow{4}{*}{ Elizabetsky } & 2007 & $y=-0.003 x+0.325$ & Decreasing \\
& 2008 & $y=0.117 x-2.123$ & Increasing \\
& 2009 & $y=-0.014 x+0.019$ & Decreasing \\
& 2010 & $y=-0.010 x-0.784$ & Decreasing \\
& 2011 & $y=-0.000 x-1.093$ & Decreasing \\
\hline \multirow{5}{*}{ Kanitz } & 2007 & $y=0.006 x+6.783$ & Increasing \\
& 2008 & $y=-0.011 x+6.127$ & Decreasing \\
& 2009 & $y=-0.016 x+7.099$ & Decreasing \\
& 2010 & $y=-0.020 x+7.060$ & Decreasing \\
& 2011 & $y=-0.007 x+5.063$ & Decreasing \\
\hline \multirow{5}{*}{ Matias } & 2007 & $y=-0.011 x+9.448$ & Decreasing \\
& 2008 & $y=1.141 x-12.99$ & Increasing \\
& 2009 & $y=-0.011 x+8.066$ & Decreasing \\
& 2010 & $y=-0.060 x+9.266$ & Decreasing \\
& 2011 & $y=0.068 x+4.155$ & Increasing \\
\hline \multirow{5}{*}{ Altman } & 2007 & $y=-0.012 x+0.410$ & Decreasing \\
& 2008 & $y=-0.003 x-0.291$ & Decreasing \\
& 2009 & $y=-0.009 x+0.356$ & Decreasing \\
& 2010 & $y=-0.008 x+0.290$ & Decreasing \\
\hline
\end{tabular}

Source: Research data.

As can be seen in Table 7 , only $20 \%$ of the results showed a positive correlation (increasing) between the levels of corporate governance and the solvency indexes, while $80 \%$ of the results showed a negative correlation (decreasing) for the same correspondents.

Following, the results obtained are discussed in detail to light of the main issues that surround the theoretical and empirical implications from the findings. 
DOI: 10.14807/ijmp.v5i4.229

\section{DISCUSSION}

Initially, it is understood that there was no a consensus among the four approaches used (Elizabetsky, Kanitz, Matias and Altman) regarding to the results of the indexes calculated. In the Elizabetsky's model, the companies analyzed proved to be insolvent. In the Kanitz's model, the companies analyzed proved to be solvents. In the Matias' model also, the companies analyzed proved to be solvents with some years, but not in all. On the other hand, the Altman's model there was a balance between the companies that were solvent and insolvent. Moreover, it has not been possible to find performance patterns or relationships among solvency indexes and levels of corporate governance only by observing the indexes descriptively.

Thus, it was performed a further analysis that could reveal related behaviors correlated between solvency indexes and the levels of corporate governance - the simple linear regression. With the regression analysis, we observed the relationships required, however, they did not show a pattern of results, indicating both positive and negative relationships, the latter being the most frequent.

Still, the fact of the indexes show that companies in a moment were in a solvency situation, and in another moment were in a insolvency situation, did not result in positive (increasing) or negative (decreasing) relationship between solvency index and level of corporate governance. That is, for both situations (solvency or insolvency) were possible to find positive and negative correlations (Table 7). It is understood is that not only models do not come into a consensus of results, but there is no relationship between solvency and level of corporate governance.

\section{FINAL CONSIDERATIONS}

This study aimed to identify whether there is a relationship between good practices of corporate governance and the solvency of companies from the Brazilian electricity sector, using to this end, four distinct models for the solvency calculation: Elizabetsky (1976), Kanitz (1978), Matias (1978) and Altman (1979). These models used for calculating the solvency index aim to identify and predict unfavorable financial situations to companies through the analysis of its financial results. Thus, the practical implication of this study is in the finding that correlations between these two factors (solvency and governance) could represent additional information to 
investors in choosing of a more viable and safe option of investment and that represents a lower risk to capital invested.

However, results show that it is not possible to affirm the existence of correlation between the solvency indexes and higher levels of corporate governance. That is, good practices of corporate governance, allowing the insertion of the companies listed on the stock exchange in a best position on the market, does not necessarily imply better solvency.

Moreover, it is noteworthy that the solvency indexes calculated should not be analyzed alone without taking into account external and internal environmental factors to the organization. As could be evidenced, this occurs because the solvency indexes did not show a consensus of results that indicates usefully which purports to predict: the solvency or insolvency. Nevertheless, solvency indexes represent additional tools and not solely sufficient to aid in decision making on the financial and economic ambit.

From this, there are some recommendations to be made for future studies related to the topic. Basically, it would be worthwhile for future studies that they reply which has been proposed here in other sectors of the economy, so that it could assess more accurately the lack of correlation between the differentiated levels of corporate governance and the solvency, or even refute the considerations raised here. Also, for future studies, it could be developed researches that use other models for calculating the solvency, such as logistic regression or neural networks.

Finally, we consider that the limitation of this study is the sample size. Regarding to the sample, it can be noticed that 11 companies are a limited number of companies to perform inferences. However, it is noteworthy that this is a sectoral study which focused strictly on a sector fairly sensitive to environmental factors, reflecting this sensibility in their indexes.

\section{REFERENCES}

ALVES, D. L.; RIBEIRO, K. C. de S.; MANTESE, F. A. de O. (2007) Governança Corporativa e o desempenho das ações de empresas do setor elétrico. In: SEMINÁRIOS EM ADMINISTRAÇÃO - SEMEAD, 10, Proceedings... São Paulo: FEA-USP.

ALMEIDA, J. C. G.; SCALZER, R. S.; COSTA, F. M. (2008) Níveis diferenciados de governança corporativa e grau de conservadorismo: estudo empírico em 
DOI: 10.14807/ijmp.v5i4.229

companhias abertas listadas na Bovespa. Revista de Contabilidade e Organizações, v. 2, n. 2, p. 118-131.

ALTMAN, E. I.; BAIDYA, T. K. N.; DIAS, L. M. R. (1979) Previsão de problemas financeiros em empresas. Revista de Administração de Empresas, v. 19, n. 1, p. 17-28.

ÁlVARES, E.; GIACOMETTI, C.; GUSSO, E. (2008) Governança corporativa: um modelo brasileiro, Rio de Janeiro: Elsevier.

ANDRADE, A.; ROSSETI, J. (2009) Governança corporativa: fundamentos, desenvolvimento e tendências, 4 ed. São Paulo: Atlas.

AGÊNCIA NACIONAL DE ENERGIA ELÉTRICA - ANEEL (2013) Medida provisória 579. [On-Line]. Retrieved from http://www.aneel.gov.br/

ASSAF NETO, A. (2002) Estrutura e análise de balanços, 7 ed. São Paulo: Atlas.

ASSAF NETO, A. (2010) Mercado financeiro, 9 ed. São Paulo: Atlas.

BAPTISTA, D. A. J. F. (2011) Estudo de solvência nas empresas concessionárias de rodovias com capital aberto. Monograph (Bachelor in Business Administration). Distrito Federal: UNB.

BHAGAT, S.; BOLTON, B. (2008) Corporate governance and firm performance. Journal of Corporate Finance, v. 14, n. 3, p. 257-273.

BLOMBERG (2013) [On-line]. Retrieved from http://www.bloomberg.com/

BM\&FBOVESPA (2009) Como e por que tornar-se uma companhia aberta utilizando $o$ mercado de capitais para crescer, [On-line]. Retrieved from http://www.bmfbovespa.com.br/pt-br/a-

bmfbovespa/download/ComoEPorque_internet.pdf

BM\&FBOVESPA (2013) A nova bolsa, [On-line]. Retrieved from http://www.bmfbovespa.com.br/home.aspx?idioma=pt-br

BRÉDART, X. (2014) Financial distress and corporate governance: the impact of board configuration. International Business Research, v. 7, n. 3, p. 72-80.

ELIZABETSKY, R. (1976) Um modelo matemático para decisão de crédito no banco comercial. Dissertation (Master in Business Administration). São Paulo: USP.

ERKENS, D. H.; HUNG, M.; MATOS, P. (2012). Corporate governance in the 20072008 financial crisis: Evidence from financial institutions worldwide. Journal of Corporate Finance, v. 18, n. 2, p. 389-411.

FERREIRA, R. do N.; SANTOS, A. C.; LOPES, A. L. M.; NAZARETH, L. G. C.; FONSESA, R. A. (2013) Governança corporativa, eficiência, produtividade e desempenho. Revista de Administração Mackenzie, v. 14, n. 4, p. 134-164.

GEOCZE, Z. B. (2010) Níveis diferenciados de governança corporativa e o efeito sobre o risco de suas ações. Revista de Finanças Aplicadas, v. 1, p. 1-23.

GIMENES, R.; URIBE-OPAZO, M. (2001) Previsão de insolvência de cooperativas agropecuárias por meio de modelos multivariados. Revista da FAE, v. 4, n. 3, p. 6578.

GITMAN, L. (2010) Princípios de administração financeira, 12 ed. São Paulo: Pearson Prentice Hall. 
GONÇALVES, T. A.; LIMA, N. C.; OLIVEIRA, S. V. W. B.; OLIVEIRA, M. M. B.; QUEIROZ, J. V. (2012) Corporate governance in financial strategy of companies listed in Bovespa. International Journal of Business and Commerce, v. 2, n. 1, p. 24-39.

IKENAGA, E.; AZEVEDO, M. A. A.; PUTVINSKIS, P. R. M R. (2009) Governança corporativa e valor do mercado de ações: Caso Eletropaulo, Light e CPFL. Monograph (Bachelor in Accounting). São Paulo: Trevisan Escola de Negócios.

KANITZ, S. C. (1978) Como prever falências, São Paulo: McGraw Hill.

KRAUTER, E.; SOUZA, A. F.; LUPORINI, C. E. M. (2005) Uma contribuição para a previsão de solvência nas empresas. In: SEMINÁRIOS EM ADMINISTRAÇÃO SEMEAD, 9, Proceedings... São Paulo:FEA-USP.

LA ROCCA, M. (2007) The influence of corporate governance on the relation between capital structure and value. Corporate Governance, v. 7, n. 3, p. 312-325.

LEV, B. (1978) Análisis de estados financieros: un nuevo enfoque, Madrid: Esic.

LOPES, J. R. da A.; MARTINS, H. C. (2007) Adesão às práticas de governança corporativa e as alterações no custo de capital de terceiros: um estudo das empresas listadas no "novo mercado" e "níveis diferenciados" da Bovespa. Revista de Administração FEAD, v. 4, p. 53-74.

LOPES, J. R. da A.; MARTINS, H. C. (2011) Alterações no custo de capital de terceiros: uma análise a partir da adesão de práticas de governança corporativa das empresas listadas no novo mercado e níveis diferenciados da Bovespa. In: Sousa Neto, J. A. De; Martins, H. C. (Orgs.), Finanças e governança corporativa práticas e estudos de caso. São Paulo: Campus, p. 188-208.

KIM, E. H.; LU, Y. (2013) Corporate governance reforms around the world and crossborder. Journal of Corporate Finance, v. 22, p. 236-253.

MACEDO, M. A. S.; CORRAR, L. J. (2009) Análise comparativa do desempenho contábil-financeiro de empresas com boas práticas de governança corporativa no Brasil. In: ENCONTRO NACIONAL DA ANPAD - ENANPAD, 33, Proceedings... São Paulo: ANPAD.

MALACRIDA, M. J. C.; YAMAMOTO, M. M. (2006) Governança corporativa: nível de evidenciação das informações e sua relação com a volatilidade das ações do Ibovespa. Revista Contabilidade e Finanças, v. 17, p. 65-79.

MÁRIO, P. do C. (2002) Contribuição ao estudo da solvência empresarial: uma análise de modelos de previsão. Estudo exploratório aplicado em empresas mineiras. Dissertation (Master in Acconting). São Paulo: USP.

MARTINS, M. S. (2003) A previsão de insolvência pelo modelo de Cox: uma contribuição para análise das companhias abertas brasileiras. Dissertation (Master in Business Administration). Rio Grande do Sul: UFRS.

MATARAZZO, D. C. (2010) Análise financeira de balanços: abordagem gerencial, 7 ed. São Paulo: Atlas.

MATIAS, A. B. (1978) Contribuição às técnicas de análise financeira: um modelo de concepção de crédito utilizando a técnica estatística de análise discriminante. Monograph (Bachelor in Business Administration). São Paulo: USP. 
MIURA, M. N.; CASTRO Jr., D. F. L.; SILVEIRA-MARTINS, E.; LIMA, N. C.; SOUZA, G. H. S. (2013) The global crisis and its impact on the index performance of BM\&FBOVESPA. Asian Journal of Business and Management Sciences, v. 2, n. 12, p. 1-12.

NASCIMENTO, S.; PEREIRA, A.; HOELTGEBAUM, M. (2010) Aplicação dos modelos de previsão de insolvências nas grandes empresas aéreas brasileiras. Revista de Contabilidade do Mestrado em Ciências Contábeis da UERJ, v. 15, n. 1, p. 40-51.

REBELLO, M. B. (2010) Modelos de previsão de insolvência: uma análise comparativa de seus resultados. Dissertation (Master in Accounting). Santa Catarina: UFSC.

REIS, A. (2009) Demonstrações contábeis: estrutura e análise, 3 ed. São Paulo: Saraiva.

REYNA, J. M. S. M.; VÁZQUEZ, R. D.; VALDÉS, A. L. (2012) Corporate governance, ownership structure and performance in Mexico. International Business Research, v. 5 , n. 11, p. $12-27$.

RIBEIRO, M. de O.; BOLIGON, J. A. R. (2009) Análise por meio de índices financeiros e econômicos: um estudo de caso em uma empresa de médio porte. Disciplinarum Scientia, v. 5, n. 1, p. 15-34.

ROGERS, P.; SECURATO, J. R.; RIBEIRO, K. C. de S. (2008) Governança corporativa, custo de capital e retorno do investimento no Brasil. REGE Revista de Gestão, v. 15, n. 1, p. 61-77.

ROSSONI, L.; MACHADO-DA-SILVA, C. L. (2013) Legitimidade, governança corporativa e desempenho: análise das empresas da BM\&FBOVESPA. Revista de Administração de Empresas, v. 53, n. 3, p. 272-289.

ROUT, U. K.; AKIMOTO, K.; SANO, F.; ODA, J.; HOMMA, T.; TOMODA, T. (2008) Impact assessment of the increase in fossil fuel prices on the global energy system, with and without $\mathrm{CO} 2$ concentration stabilization. Energy Policy, v. 36, n. 9, p. 34773484.

SAMOHYL, R. W. (2009) Controle estatístico de qualidade, Rio de Janeiro: Elsevier.

SERAFIM, L. S.; GOMES, L. L. (2011) Influência da governança corporativa nas ações do setor elétrico brasileiro: uma análise através da medida ômega. Final Report of Pibic (Scientific Initiation in Business Administration). Rio de Janeiro: PUCRJ.

SILVA, J. (2008) Análise financeira das empresas, 9 ed. São Paulo: Atlas.

SILVA, R. M. da L. (2010) Volatilidade dos retornos e governança: um estudo de eventos da crise do Subprime. Dissertation (Master in Business Administration). Rio Grande do Norte: UFRN.

SILVA Jr., R. R.; JUNQUEIRA, L. R; BERTUCCI, L. A. (2009) A relação entre a adoção das práticas da governança corporativa e a alavancagem financeira das empresas brasileiras do setor energético no ano de 2008. Gestão e Sociedade, v. 3, n. 6, p. 315-334. 
SILVEIRA, A. D. M. (2002) Governança corporativa, desempenho e valor da empresa no Brasil. Dissertation (Master in Business Administration). São Paulo: USP.

TALAMO, G. (2011) Corporate governance and capital flows. Corporate Governance, v. 11, n. 3, p. 228-243.

WANG, X.; DENNIS, L.; TU, Y. S. (2007) Measuring financial condition: a study of U.S. States. Public Budgeting \& Finance, v. 27, n. 2, p. 1-21.

ZIM, R. A. (2009) A política de gestão de riscos e o conflito de agência. Thesis (Doctorate in Business Administration). Rio Grande do Sul: UFRS. 